подготовки: дис. ... канд. пед. наук : спец. 13.00 .02 «Теория и методика обучения (технические дисциплины)»/ Кушнир Ольга Александровна. - Кировоград, 2009. 282 c. 4. Макаров Р. Н. Основы формирования профессиональной надёжности лётного состава гражданской авиации : [учеб. пособ.] / Р. Н. Макаров - М. : Воздушный транспорт, 1990. - 384 с. 5. Плотников Н. И. Ресурсы воздушного транспорта: [монография] / Николай Иванович Плотников. - Новосибирск : НГАЭиУ, 2003. - 328 с. 6. Практикум по дифференциальной психодиагностике профессиональной пригодности / [редколл. : В. А. Бодров (отв. редактор) и др.]. - М. : ПЕР СЭ, 2003.768 с. 7. Шадриков Б. Д. Психология деятельности и способности человека: [учеб. пособ.] / В. Д. Шадриков. - М. : Логос, 1996. - 320 с. 8. Энциклопедический словарь: психология труда, управления, инженерная психология и эргономика / [редкол.: Б. А. Душков (отв. редактор) и др.]. - М. : Академический проект, 2005. - 848 с. 9. Endsley M. Pilot situation awareness: The challenge for the training community. In Proceedings of the Interservice/ Industry Training Systems Conference (I/ITSC), 1989. P. 111-117. Ft. Worth, TX: American Defense Preparedness Association. 10. Gibson J., Orasanu J., Villeda E., Nygren T. (Loss of situation awareness: causes and consequences. In R.S. Jensen \& R.L.A. (Eds.), Proceedings of the Eigth International Symposium on Aviation Psychology, 1997. - Vol. 2. - P. 1417-1421. - Columbus: The Ohio State University.

\title{
Світлана Майданенко
}

\section{АНАЛІЗ СТРУКТУРИ ОРГАНІЗАЦЇ̈ МЕТОДИЧНОЇ РОБОТИ В ПЕДАГОГІЧНОМУ УЧИЛИЩІ}

Майданенко С. В. Аналіз структури організації методичної роботи в педагогічному училищі.

У статті розмежовано внутрішню та зовнішню організацію методичної роботи в педагогічному училищі. Конкретизовано рівні внутрішньої організації методичної роботи.

Ключові слова: внутрішня організація, зовнішня організація, загальна структура, рівні внутрішньої структури.

Майданенко С. В. Анализ структуры организации методической работы в педагогическом училище.

В статье выделены внутренняя и внешняя организация методической работы в педагогическом училище. Конкретизированы уровни внутренней организации методической работы.

Ключевые слова: внутренняя организация, внешняя организация, общая структура, уровни внутренней структуры.

Maidanenko S. V. Analysis of the structure of organization of methodological work in the pedagogic professional school. The article highlighted the internal and external organisation of methodical work in the pedagogic professional school. Author specifies the levels of the internal organization of methodical work.

Key words: internal organization, foreign organization, the overall structure, levels of internal structure.

У реформуванні національної освіти в Україні важливого значення набуває організація методичної роботи у навчальних закладах, головною метою якої є допомога 
педагогам у розвитку професійної компетентності, вдосконалення і підвищення педагогічної майстерності та активізація їхнього творчого потенціалу.

Багато науковців розглядають проблему організації методичної роботи в школі (Ю. Бабанський, Н. Волкова, В. Кудзоєва, Т. Рабченюк та інші). Зазначимо, що має місце досить неординарний підхід до визначення самої суті цього поняття. Одні автори розглядають це поняття як форму організації підвищення професійності вчителів (Ю. Бабанський, Н. Волкова, В. Кудзоєва, Т. Рабченюк та інші), як умову розвитку педагогічної творчості педагогів (Т. Берсенєва, Л. Білієнко, Н. Дудниченко, В. Загвязинський, С. Максимюк, Є. Повар), як допомогу у формуванні наукової організації навчального процесу (Г. Азаріашвілі, В. Головінов і В. Головінова, I. Жерносєк, В. Зотова, О. Остапчук), як засвоєння досягнень науки і передового досвіду (Г. Гребенюк, О. Деменцев, І. Жерносєк, Ф. Касабаєва, К. Кіндрат, Ф. Красовський, Р. Кулдавлєтов, В. Лозовецька, М. Нікандров, С. Петрова та інші); інші - як організацію підвищення кваліфікації та атестації педагогічних працівників (Т. Абдулаєв, О. Автомонова, В. Бондар, Х. Золотар, С. Мануйленко, О. Овдієнко).

Meта cmammi- проаналізувати внутрішню та зовнішню структуру організації методичної роботи в педагогічному училищі, виокремити загальну структуру організації методичної роботи.

У здійсненому аналізі внутрішньої структури організації методичної роботи ми використовували теоретико-методологічні принципи (принцип детермінізму, цілісності, системності і структурності, необхідності вивчення співвідношення загального i часткового). 3 нашої точки зору, внутрішня структура методичної роботи складається 3 двох базових рівнів, які передбачають розгляд особливостей організації методичної роботи, що представлені в таблиці 1.

\section{Внутрішня структура організації методичної роботи в педагогічному училищі}

\begin{tabular}{|c|c|}
\hline $\begin{array}{c}\text { Перший рівень організації } \\
\text { методичної роботи }\end{array}$ & $\begin{array}{c}\text { Другий рівень організації } \\
\text { методичної роботи }\end{array}$ \\
\hline $\begin{array}{c}\text { Організація методичної роботи } \\
\text { в педагогічному училищі }\end{array}$ & $\begin{array}{c}\text { Психолого-педагогічна } \\
\text { готовність учасників до } \\
\text { організації методичної роботи }\end{array}$ \\
\hline $\begin{array}{c}\text { Планування діяльності методичної } \\
\text { роботи в педагогічному училищі }\end{array}$ & $\begin{array}{c}\text { Мотивацій показник на наукову } \\
\text { організацію управління } \\
\text { педагогічним колективом у } \\
\text { методичній роботі }\end{array}$ \\
\hline $\begin{array}{c}\text { Виконання методичної роботи } \\
\text { в педагогічному училищі }\end{array}$ & $\begin{array}{c}\text { Змістовий показник - усвідомлення } \\
\text { знань про інноваційне управління } \\
\text { методичною роботою }\end{array}$ \\
\hline $\begin{array}{c}\text { Контроль діяльності учасників } \\
\text { методичної роботи }\end{array}$ & $\begin{array}{c}\text { Дієвий показник - інноваційна } \\
\text { спрямованість навчання студентів }\end{array}$ \\
\hline $\begin{array}{c}\text { Корекція і координація з підвищення } \\
\text { ефективності методичної роботи } \\
\text { в педагогічному училищі }\end{array}$ & $\begin{array}{c}\text { Особистісний показник - розвиток } \\
\text { інноваційного мислення і } \\
\text { гуманістичної спрямованості } \\
\text { викладача }\end{array}$ \\
\hline
\end{tabular}


Перший рівень внутрішньої структури організації методичної роботи складається з чотирьох компонентів: 1. Планування діяльності методичної роботи в педагогічному училищі. 2. Керівництво методичною роботою в педагогічному училищі. 3. Контроль діяльності учасників методичної роботи. 4. Корекція і координація методичної роботи.

Проаналізувавши погляди різних науковців на сутність готовності керівників до організації методичної роботи, ми визначаємо це поняття як складне особистісне утворення, яке містить у собі усвідомлене оперування знаннями, уміннями і навичками планувати, керувати, контролювати і здійснювати корекцію змісту і завдань методичної роботи задля досягнення сформованої педагогічної культури у викладачів.

Другий рівень внутрішньої структури організації методичної роботи передбачає психолого-педагогічну готовність керівників і викладачів педагогічного училища до участі в методичній роботі. Теоретичний аналіз дозволяє нам виокремити такі компоненти: 1. Мотиваційний показник управління педагогічним колективом у методичній роботі і мотиваційний компонент заохочення викладачів до цієї роботи. 2. Змістовий показник усвідомлених знань про інноваційне управління методичною роботою. 3. Дієвий показник - інноваційна спрямованість навчання студентів. 4. Особистісний показник розвиток інноваційного мислення і гуманістичної спрямованості викладача.

Загальна структура організації методичної роботи представлена на рис. 1 .

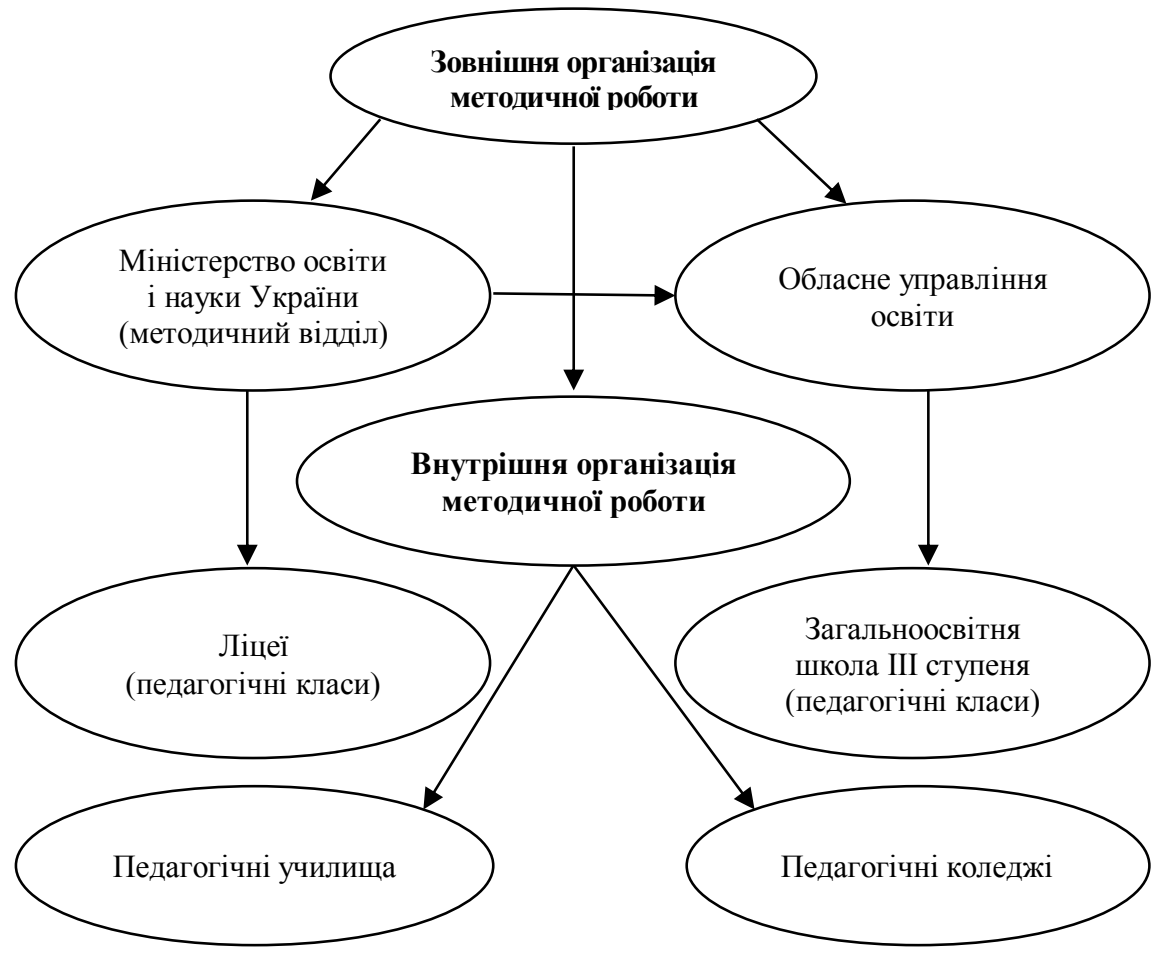

Рис. 1. Загальна структура організації методичної роботи 
Кожен із структурних елементів організації методичної роботи у педагогічному училищі має свій зміст та призначення.

Розглянемо перший рівень організації методичної роботи - Інноваційне управління методичною роботою в педагогічному училищі.

Компонент «Планування діяльності методичної роботи в педагогічному училищі» розглядається нами як стратегічне і тактичне планування. Стратегічне плануванняце вміння враховувати місію (мету) навчального закладу, концептуальну модель та програму розвитку училища, визначення основних інноваційних ідей та підходів у методичній роботі. Тактичне планування забезпечується в результаті складання планів, які визначають спрямованість та зміст організації методичної роботи на певний період.

Компонент «Керівництво методичною роботою в педагогічному училищі» ми розглядаємо як створення певної структури, яка дає можливість учасникам методичної роботи ефективно працювати для досягнення стратегічних i тактичних цілей, поставлених перед ними, та забезпечує чітку взаємодію між ії основними підрозділами й викладачами.

Щодо компонента «Контроль діяльності учасників методичної роботи» ми визначаємо показник, наскільки реалізуються цілі, поставлені перед учасниками методичної роботи на етапі планування, виконання і результативності підвищення професійно-педагогічної компетентності.

У компоненті «Корекиія $i$ координація методичної роботи в педагогічному училищі » ми визначаємо результат досягнення кінцевого «продукту» функціонування методичної роботи. Зауважимо, що кінцевий «продукт» діяльності викладача хоча й не матеріальний, тобто «неживий», все ж таки існує, і за своїм параметром він є складним показником ефективності педагогічної діяльності викладачів як результат підготовки спеціаліста освітньо-кваліфікаційного рівня «Молодший спеціаліст».

Обгрунтуємо «Другий рівень організації методичної роботи». Дослідження показало, що психолого-педагогічна готовність учасників методичної роботи - це комплекс мотивів, знань, умінь та навичок, особистісних якостей, які забезпечують успішну взаємодію керівників методичної роботи 3 викладачами та ефективність цієї взаємодії загалом. За своєю структурою вона становить складне, багатоаспектне особистісне утворення, яке охоплює функціонально пов'язані між собою та взаємозумовлені такі компоненти.

Мотиваційний компонент - це сукупність мотивів адекватних цілям та завданням методичної роботи. Як показало наше дослідження, до цієї групи мотивів входять такі мотиви: гордість за свій навчальний заклад та педагогічний колектив; реальний внесок у підвищення свого професійного рівня; намагання формувати висококваліфікованого майбутнього вихователя і вчителя початкових класів.

Показник знань, умінь $i$ навичок розглядається нами як когнітивний $i$ дієвий компоненти. Когнітивний компонент - це сукупність знань, необхідних для управління методичною роботою. Згідно 3 місією (метою) педагогічного училища, ми визначаємо такі показники цього компонента: знання психології і педагогіки, знання навчальної дисципліни та методики іiі викладання. Дієвий показник- це сукупність умінь та навичок, які забезпечують успішність здійснення управління методичною роботою завдяки сформованим умінням та навичкам: діагностувально-прогностичні (проективні) $і$ організаційно-регулятивні. Діагностувально-проективні уміння надають змогу визначати основні завдання у плануванні методичної роботи, здійснювати контроль успішності методичної роботи, забезпечувати особистісно зорієнтований підхід до кожного учасника методичної роботи 3 урахуванням його професійних інтересів і потреб. 
Організаційно-регулятивні вміння і навички сприяють розподілу обов'язків в організації методичної роботи, мобілізації педагогічного колективу на виконання актуальних навчально-виховних завдань.

Особистісний компонент - це система особистісних характеристик керівників і викладачів. Кожен 3 них несе особисту відповідальність за весь процес методичної роботи, ефективність якої залежить від ставлення до методичної роботи, з одного боку, з іншого, - ії ефективність зумовлена компетентністю, високим інтелектуальним рівнем, творчим потенціалом, комунікативними та організаторськими здібностями.

Аналіз зовнішньої структури організації методичної роботи в закладах освіти передбачає розгляд того, у яких напрямках здійснюється управління в цій роботі. Зовнішня структура організації методичної роботи в системі освіти представлена в таблиці 2.

Таблиця 2

Зовнішня структура організації методичної роботи в системі освіти

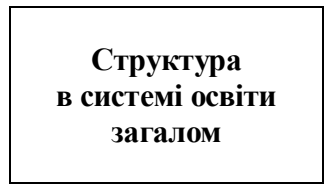

\begin{tabular}{|l|}
\hline $\begin{array}{l}\text { Міністерство освіти } \\
\text { і науки України }\end{array}$ \\
\hline $\begin{array}{l}\text { Управління освіти } \\
\text { обласних } \\
\text { держадміністрацій }\end{array}$ \\
\hline $\begin{array}{l}\text { Управління відділів } \\
\text { освіти міських, } \\
\text { районних державних } \\
\text { адміністрацій }\end{array}$ \\
\hline $\begin{array}{l}\text { Навчальні заклади } \\
\text { освіти }\end{array}$ \\
\hline
\end{tabular}

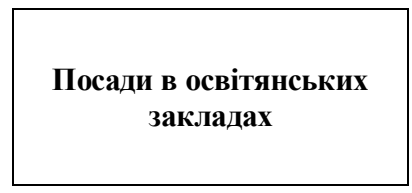

\begin{tabular}{|l|}
\hline Начальник обласного \\
(міського, районного) \\
управління (відділу) освіти \\
і науки; ректор (директор) \\
навчального закладу \\
\hline Заступник начальника \\
обласного (міського, \\
районного) управління \\
(відділу) освіти, \\
проректори (заступники \\
директора) \\
\hline Інспектори обласних \\
(міських, районних) \\
управлінь (відділів) освіти \\
і науки, викладачі \\
(вчителі) \\
\hline Об’єкт управлінського та \\
педагогічного впливу \\
(студенти, учні та їх \\
батьки) \\
\hline
\end{tabular}

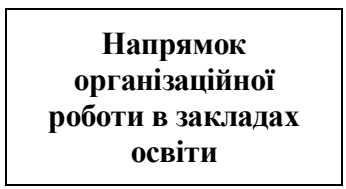

Визначення стратегії та тактики діяльності освітніх закладів

«Управлінська
команда» та
педагогічні кадри

$\begin{aligned} & \text { Науково-методичне } \\ & \text { забезпечення } \\ & \text { навчально-виховної } \\ & \text { діяльності }\end{aligned}$
$\begin{aligned} & \text { Підвищення } \\ & \text { кваліфікації кадрів та } \\ & \text { іх атестації }\end{aligned}$

Отже, структуру організації методичної роботи в педагогічному училищі визначаємо як цілісну систему, що охоплює «зовнішню» і «внутрішню» структуру організації підвищення професійного рівня педагогічної діяльності викладача.

\section{Література}

1. Майданенко С. В. Організація методичної роботи в педагогічному училищі в умовах реалізації ступеневої професійної освіти вчителя: дис. ... канд. пед. наук / С. В. Майданенко. - Кривий ріг, 2007. - 215 с. 2. Методичні служби України: проблема 
управління, професійна підготовка: [навч.-метод. посібн.] / за ред. Г. С. Данилова. - К. : I3MH, 1997. 3. Prosser J. School culture / J. Prosser. - London: Paul Chaptan Publising. 1999. 4. Taylor F. The principles of Scientific Management/ F. Taylor. - N.Y., 1911.

УДК 378.091.12.011.3’051:81’243

Людмила Петько

\section{ІНШОМОВНА ОСВІТА В КОНТЕКСТІ ФОРМУВАННЯ НОВОГО ВЧИТЕЛЯ В УМОВАХ УНІВЕРСИТЕТСЬКОЇ ПІДГОТОВКИ}

Петько Л. В. Іншомовна освіта в контексті формування нового вчителя в умовах університетської підготовки.

Автор статті розкриває сучасні підходи до розуміння та розгортання іншомовної освіти майбутніх педагогів в умовах університетської підготовки. Обгрунтовується необхідність формування нового педагога, сучасної полілінгвальної особистості у процесі навчання іноземних мов за професійним спрямуванням студентів ВНЗ.

Ключові слова: професійна педагогіка, іншомовна освіта, майбутні вчителі, іноземні мови за професійним спрмуванням, університет.

Петько Л. В. Иноязычное образование в контексте формирования нового учителя в условиях университетской подготовки.

Автор статьи раскрывает современные подходы к пониманию и развёртыванию иноязычного образования в условиях университетской подготовки будущих педагогов. Обосновывается необходимость формирования нового педагога, современной полилингвальной личности в процесе обучения иностранным языкам профессиональной направленности студентов ВНЗ.

Ключевые слова: профессиональная педагогика, иноязычное образование, будущие учителя, иностранные языки профессиональной направленности, университет.

Pet'ko L. V. University foreign language education in the context of the formation of a new teacher.

The author examines the modern approaches to the understanding and developing of foreign language education of future teachers in the university training.

The article describes necessity of forming of a new teacher, who will be a modern personality, in the process of foreign language teaching in professional way of the students of higher educational establishments.

Key words: professional pedagogy, university foreign language education, future teachers, foreign language in professional way.

У глобальних умовах формується новітня педагогічна парадигма сучасної освіти, яка, з одного боку, характеризується, складністю, суперечливістю, незбалансованістю, наявністю різновекторних підходів, а з іншого - дозволяє раціоналізувати дії залучених до неї учасників, зумовлює виникнення нової системи зв' язків між суб' єктами, гарантує динамічні конкурентні переваги, що окреслено в Педагогічній Конституції Європи (2013) [1]. Нині сучасна педагогічна парадигма освіти припускає можливість коригування іiі форм та змісту. Саме тому особливо важливим $є$ визначення місця і ролі окремих іiї ланок, з-поміж яких однією з головних $є$ іншомовна освіта.

Сучасні проблеми глобалізаційних перспектив, що спричиняють політичні, соціальні та культурно-цивілізаційні наслідки, зумовили зміну соціального замовлення щодо освіти й орієнтують вищу педагогічну освіту на розв' язання пріоритетних завдань, 